\title{
Benthic infaunal community structuring in an acidified tropical estuarine system
}

M Belal Hossain ${ }^{1,2^{*}}$ and David J Marshall ${ }^{1}$

\begin{abstract}
Background: Recent studies suggest that increasing ocean acidification (OA) should have strong direct and indirect influences on marine invertebrates. While most theory and application for OA is based on relatively physically-stable oceanic ecological systems, less is known about the effects of acidification on nearshore and estuarine systems. Here, we investigated the structuring of a benthic infaunal community in a tropical estuarine system, along a steep salinity and pH gradient, arising largely from acid-sulphate groundwater inflows (Sungai Brunei Estuary, Borneo, July 2011- June 2012).

Results: Preliminary data indicate that sediment pore-water salinity (range: 8.07 - 29.6 psu) declined towards the mainland in correspondence with the above-sediment estuarine water salinity (range: $3.58-31.2 \mathrm{psu}$ ), whereas the pore-water $\mathrm{pH}$ (range: 6.47- 7.72) was generally lower and less variable than the estuarine water pH (range: 5.78- 8.3), along the estuary. Of the thirty six species (taxa) recorded, the polychaetes Neanthes sp., Onuphis conchylega, Nereididae sp. and the amphipod Corophiidae sp., were numerically dominant. Calcified microcrustaceans (e.g., Cyclopoida sp. and Corophiidae sp.) were abundant at all stations and there was no clear distinction in distribution pattern along the estuarine between calcified and non-calcified groups. Species richness increased seawards, though abundance (density) showed no distinct directional trend. Diversity indices were generally positively correlated (Spearman's rank correlation) with salinity and $\mathrm{pH}(\mathrm{p}<0.05)$ and negatively with clay and organic matter, except for evenness values $(p>0.05)$. Three faunistic assemblages were distinguished: (1) nereid-cyclopoid-sabellid, (2) corophiid-capitellid and (3) onuphid- nereid-capitellid. These respectively associated with lower salinity/pH and a muddy bottom, low salinity/pH and a sandy bottom, and high salinity/pH and a sandy bottom. However, CCA suggested that species distribution and community structuring is more strongly influenced by sediment particle characteristics than by the chemical properties of the water (pH and salinity).
\end{abstract}

Conclusions: Infaunal estuarine communities, which are typically adapted to survive relatively acidic conditions, may be less exposed, less sensitive, and less vulnerable than epibenthic or pelagic communities to further acidification of above-sediment waters. These data question the extent to which all marine infaunal communities, including oceanic communities, are likely to be affected by future global $\mathrm{CO}_{2}$-driven acidification.

Keywords: Community structure, Infauna, Soft-bottom, Tropical estuary, Salinity, Acidification

\section{Background}

Many tropical and subtropical estuaries experience acidification (low $\mathrm{pH}$ ) resulting from acid sulfate soil (ASS) inflows [1-5]. ASS perturbation occurs when pyrite is produced during bacterial breakdown of organic matter in the presence of sulfate and iron oxides in sediments [1]. Though the estuarine $\mathrm{pH}$ levels generally vary from

\footnotetext{
*Correspondence: mbhnstu@gmail.com

${ }^{1}$ Environmental and Life Sciences, Faculty of Science, Universiti Brunei Darussalam, BE1410 Jalan Tunkgu Link, Brunei Darussalam

${ }^{2}$ Department of Fisheries and Marine Science, Noakhali Science and Technology University, Sonapur 3814, Bangladesh
}

7.0 to 7.5 in the fresher sections, to between 8.0 and 8.6 in the more saline areas [6]; the runoff from the ASS can reduce the $\mathrm{pH}$ of adjacent estuaries to as low as 2 [7]. Many studies have demonstrated that aquatic organisms have trouble surviving if $\mathrm{pH}$ levels drop under 5 or rise above 9 [7-9]. Fluctuating $\mathrm{pH}$ may compromise optimally related life processes (such as metabolism and growth), but also potentially increase the solubility of calcium carbonates and the bioavailability of metals $[8,10]$. In the acidic condition, toxic metals in the estuarine sediment can be resuspended in the water columns which have indirect detrimental impacts on many 
organisms. Field and short-term laboratory studies have shown that ASS runoff can cause significant shell dissolution and perforation of heavily shelled organisms, e.g. bivalves (oyster) and gastropods [1,10,11]. However, less information is available for non or weakly calcified organisms (crustaceans, polychaetes) and for community level responses in general for extraordinarily acidified tropical estuaries [3-5]. The timeframes for exposure to ASS groundwater runoff in estuarine systems are unclear, but exposure could last for decades or hundreds of years, allowing assessment of multi-generational impacts of low $\mathrm{pH}$ on biological systems [3].

In addition to ASS acidification, it is possible that estuarine biota may face increasing acidification stress through present and future elevations in atmospheric $\mathrm{CO}_{2}$, a phenomenon affecting oceanic waters, known as 'ocean acidification' [10,12-15]. Because ocean acidification affects the balance of the carbonate systems, shelled organisms possessing calcium carbonate structures are expected to be especially threatened by this process. This brings to question how future OA might affect estuarine systems, and raises the importance of understanding of benthic community structuring in already acidified tropical estuarine systems. The few investigations that have looked at the effects of acidification on benthic fauna of estuaries have reported lower diversity and abundance in soft bottom communities in the acidified sites compared to reference sites $[3,16,17]$. However, these studies have mainly focused on the effects of ASS water inflows on epibenthic communities, without considering relationships between the pore-water $\mathrm{pH} /$ salinity and the faunas living within sediments. Soft-bottom infaunal organisms are expected to experience $\mathrm{pH}$ levels lower than those in the water column as a consequence of significant microbial and animal metabolism (including sulphide production) and poor ventilation within sediments.

Recent studies suggest that increasing acidification should have strong direct and indirect effects on marine invertebrates. These studies sometimes exclude details of the structural complexity, ecophysiological variability and genetic diversity characterizing natural communities [18]. It is however likely that communities which have evolved in acidified coastal and marine environments (such as acidified estuaries), possess species already well adapted for acidification exposure. Structural complexity should arise from taxonomic differences in physiological and behavioural adaptations, and tolerances, of low $\mathrm{pH}$. As an example, crustaceans (crabs and prawns) are possibly better at tolerating reduced $\mathrm{pH}$, given their ability to generally to regulate internal body fluids (with respect to most ions), compared to other taxa for which body fluids conform in ionic concentrations relative to the external environment (annelids and molluscs; see Wittman and Portner [19]). However, regulation comes at an energetic cost, and some groups are well adapted, behaviourally and physiologically, to isolate themselves from environmental perturbations. Furthermore, no studies found to show how benthic infaunal animals and communities (as opposed to epibenthic communities) of any marine system, which experience relatively stable, low pore-water $\mathrm{pH}$ 's, are likely to respond to atmospheric $\mathrm{CO}_{2}$-driven future acidification of marine waters.

The distributions of estuarine benthic faunas are well known to vary in relation to a variety of physicochemical gradients $[20,21]$. The main factors, however, that regulate benthic species composition and density are salinity, dissolved oxygen and substratum particle composition $[20,22,23]$. Among these variables, salinity fluctuations are usually overwhelming in their effect on the structure and functioning of estuarine systems [21,23-25]. Additionally, in the case of benthic infaunal communities, sediment granulometry has proven to be important [23], especially considering that estuarine sediments are extremely dynamic, comprising a variety of substrata from non-vegetated soft mud, fine and coarse sand, to vegetated saltmarsh, algal mats, seagrass beds and mangrove swamps [21,24].

Given the fact that physical stressors are likely to increase with reductions in salinity and $\mathrm{pH}$ of estuarine waters, we investigated whether communities in regions occupying low salinity/high acidity are characterized by relatively lowered abundance and diversity, in the case of benthic infauna communities of acidified estuarine systems. In particular, we determined variation in species abundance, species diversity and the structuring of these communities along the steep salinity and $\mathrm{pH}$ gradient of the Brunei estuarine system (BES, Brunei Darussalam, tropical South East Asia, Borneo). We further assessed the interaction strength for community attributes and the environmental parameters, including sediment properties.

\section{Results}

\section{Pore-water characteristics}

Overall the pore-water salinity varied between 8.07 and $29.6 \mathrm{psu}$, and $\mathrm{pH}$ between 6.47 and 7.72. Pore-water salinity was generally greater than the above-sediment water salinity, though these were well linearly related (pore water salinity $=7.62+0.72$ overlying water salinity; $\mathrm{r}^{2}=0.875$ for means at each station, $\mathrm{p}=0.062$ ) (Figure 1A). However, there was a poor relationship between pore-water and above-sediment estuarine water in the case of $\mathrm{pH}$ (porewater $\mathrm{pH}=5.49+0.228$ overlying water $\mathrm{pH} ; \mathrm{r}^{2}=0.63$, $\mathrm{p}=0.2$ ), due to in situ sediment biotic generation of fulvic and humic acids (through heterotrophic metabolism) at stations having relatively high $\mathrm{pH}$ (S5 for example) (Figure 1B). Nonetheless there was an overall tendency for pore-water salinity and $\mathrm{pH}$ to vary as predicted (low landwards and high seawards). The relationship between pore-water salinity and $\mathrm{pH}$ is: $\mathrm{pH}=0.035$ Salinity +6.42 (Figure $1 \mathrm{C}$ ). 

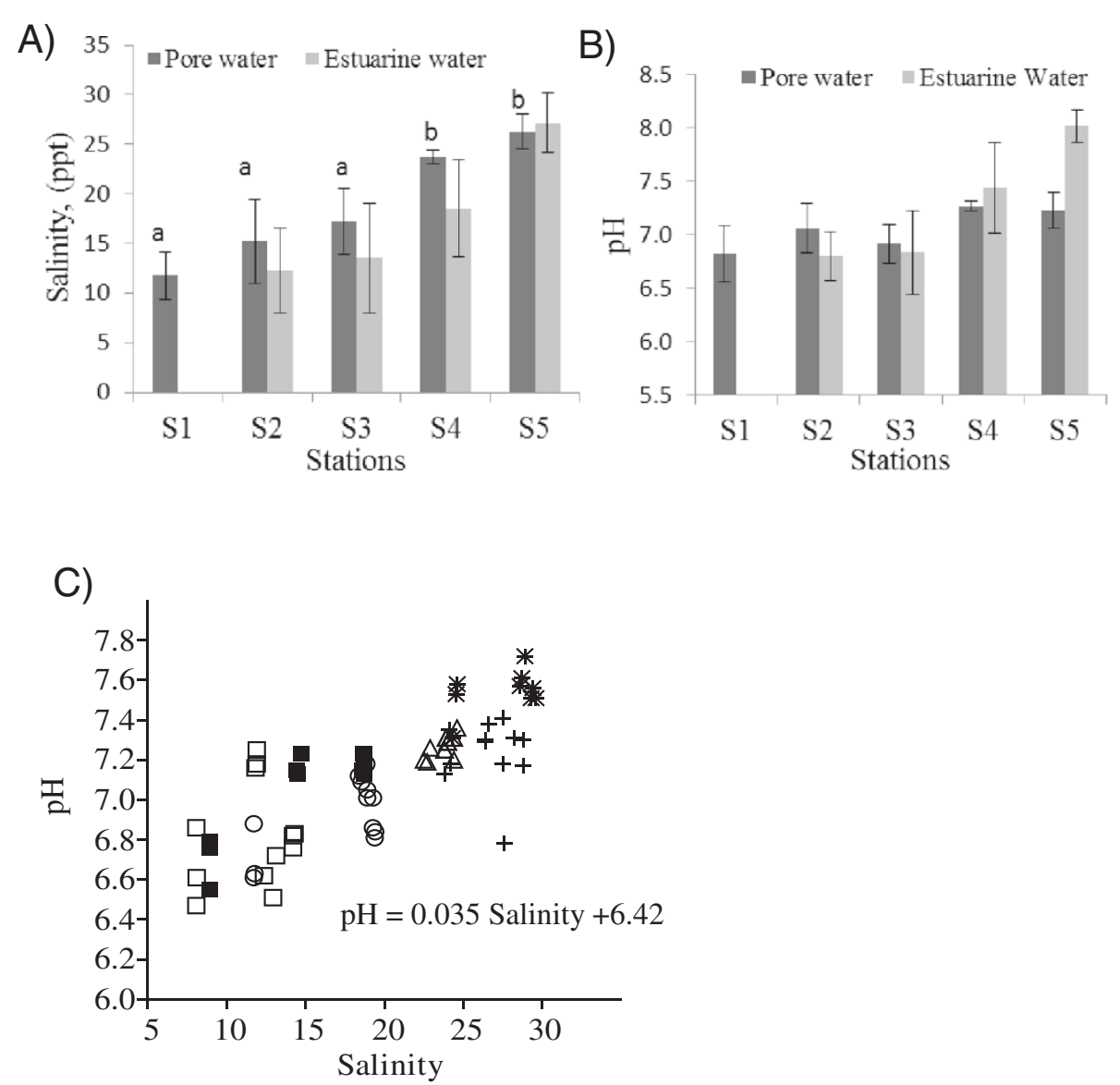

Figure 1 Sediment pore-water and above-sediment estuarine water properties at the five stations along the BES. Stations differed significantly in pore-water salinity (Wald $=121.2 ; \mathrm{p}<0.001$ ) [A] and $\mathrm{pH}$ (Wald $=14.2 ; \mathrm{p}<0.006$ ) $[\mathbf{B}]$. ' $a$ ' and 'b' indicating significant difference at $5 \%$ level. The pore-water salinity and pH is correlated [C]. Estuarine water salinity and pH data were taken from Marshall et al. [11]; their study did not cover the site $\mathrm{S} 1$, hence the salinity and $\mathrm{pH}$ data were not available for S1.

\section{Species composition}

A total of 4174 individuals, belonging to 36 species from six taxonomic groups (Polychaeta, Copepoda, Amphipoda, Tanaidacea, Cumacea and Isopoda) were recorded in the Brunei estuarine system over the sampling period. The dominant group both in number of species ( 25 species) and individuals (75\%) was the Polychaeta. Composition of species in different stations along the estuary clearly differed. The 10 most abundant species in the estuary, representing 93.3\% of the collected benthic infauna, were Neanthes sp. (23.2\%), Onuphis conchylega (9.8\%), Nereididae sp.2 (9.7\%), Corophiidae sp. (8.7\%), Capitellidae sp.1 (8.3\%), Cyclopoida sp. (7.9\%), Goniada sp.(5.6\%), Nereididae sp.3 (5.2\%), Prionospio sp. (2.5\%) and Amphipoda sp. 2 (2.44\%). The dominant species also varied for different stations along the estuary: Nereididae sp.2 (43.8\%) at S1, Neanthes sp. (35.0\%) at S2, Corophiidae sp. (46.4\%) at S3, Onuphis conchylega (18.4\%) at S4 and Capitellidae sp.1 (21.1\%) at S5.

Analyses based on the distinction of calcifiers and noncalcifiers, showed that calcifiers were highest (62.14\%) in the inner low pH station (S3) and the lowest (8.80\%) in the downstream station (S4) (Figure 2). In contrast, noncalcifiers were the highest $(91.20 \%)$ in the downstream high $\mathrm{pH}$ station (S4) and the lowest (37.86\%) in the acidic station (S3). Although, there was no clear spatial trend in their \% composition and mean abundance (Figure 2) along estuarine $\mathrm{pH}$ gradient, but species number of calcifiers and non-calcifiers tended to increase towards high $\mathrm{pH}$ downstream stations (Figure 2). All species were included for data analysis.

\section{Variation of community parameters}

Spatial variation in the number of species, density, species richness and diversity values for each station are presented in Figure 3. Except for evenness $\left(\lambda^{2}=1.46, \mathrm{df}=4, \mathrm{p}=0.83\right)$, which was uniform among the stations, Kruskal-Wallis ANOVA indicated significant differences in species number $\left(\lambda^{2}=40.86, \mathrm{df}=4, \mathrm{p}<0.001\right)$, density $\left(\lambda^{2}=14.72, \mathrm{df}=4\right.$, $\mathrm{p}<0.01)$, species richness $\left(\lambda^{2}=38.18, \mathrm{df}=4, \mathrm{p}<0.001\right)$ and diversity $\left(\lambda^{2}=25.01, \mathrm{df}=4, \mathrm{p}<0.001\right)$. The mean overall 


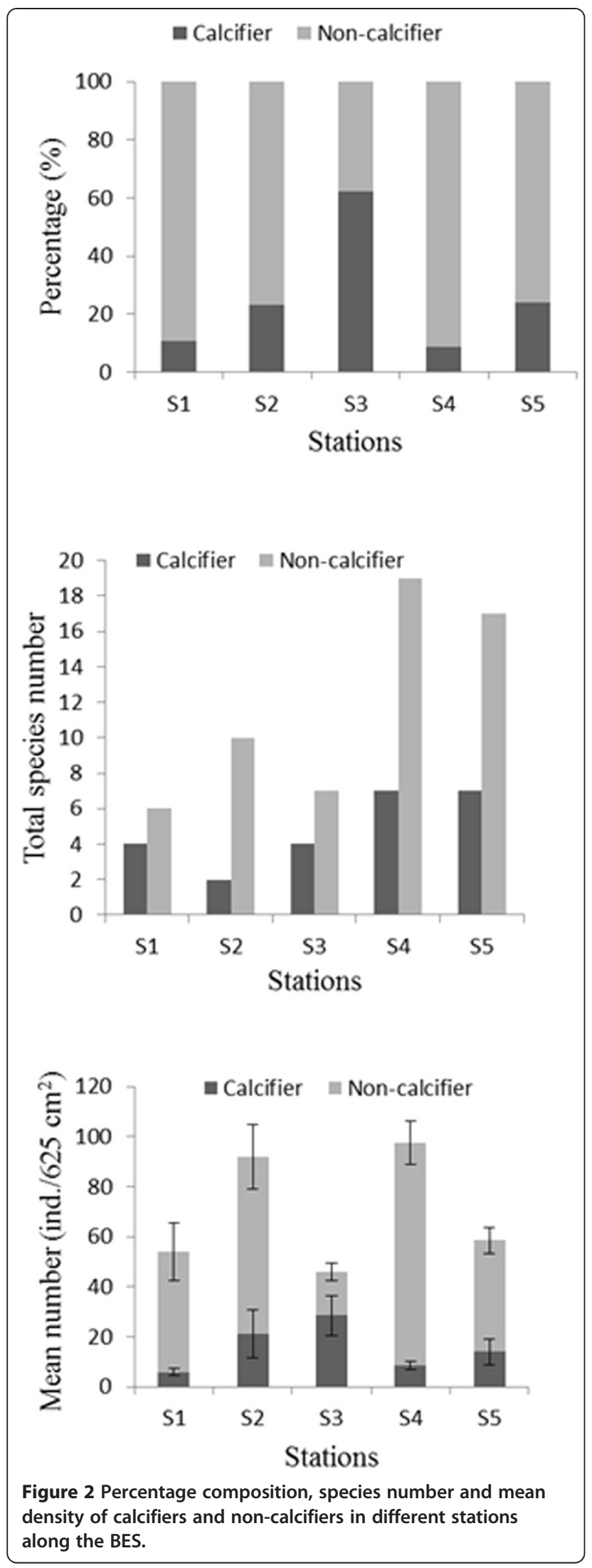

species number and density per site ranged from 4 to 15 (mean 8) and 46 to 97 (mean 69) ind.625 $\mathrm{cm}^{-2}$ respectively. Species diversity and richness per site ranged from 1.01 to 3.15 (mean 1.72) and 0.98 to 2.03 (mean 1.38). All the measured diversity indices were the highest at station 4 and the lowest at station 3 (Figure 3). Species diversity and richness varied among sites, with a general trend of outer sites (e.g., 4 and 5) having significantly higher values than those in inner sites (e.g., 1, 2 and 3) $(P<0.05$ for all).

\section{Variation of community structure}

The MDS ordination grouped the infaunal assemblages into three main groups at $20 \%$ similarity level: the innermost stations S1 and S2, inner stations S3 and the outer stations S4 and S5 (Figure 4) and showed a horizontal zonation of assemblages, clearly separating outer stations from the rest of the inner stations. The low-stress value $(r=0.15)$ in MDS showed that the community structure is well represented. Within each location, samples clustered mostly with those from the same sampling site. Samples between sites did not show a high level of similarity as indicated by the long terminal branches. The ANOSIM test confirmed the significant differences among stations (Global $\mathrm{R}=0.977, \mathrm{p}<0.001$ ) (Table 1). R-statistic values for pair-wise comparisons provided by ANOSIM were used here to determine the dissimilarity between groups. Values close to 1 indicate very different composition, while values near zero show small difference. There was also a statistical evidence of temporal variability in infaunal assemblages between sampling periods (Global $\mathrm{R}=0.548, \mathrm{p}<0.001$ ). SIMPER analysis of infaunal abundance data revealed that the innermost stations (S1 and S2) group was dominated by Nereididae sp.2, Neanthes sp. and Cylopoida sp., and the outer stations group ( 44 and S5) by Onuphis conchylega, Capitellidae sp.1, Nereididae sp.3 and Goniada sp (Table 2). SIMPER revealed the average Bray-Curtis dissimilarity between locations ranged from 61.72 to $91.80 \%$. The seaward station S4 had the highest dissimilarity values for infaunal species with most landward stations S1 (91.8\%) and S2 (88.30\%). The high abundance of Onuphis conchylega at S4 and absence of this species in S1 and S2 was a key cause of these high dissimilarities. S1 had an average dissimilarity of $82.9 \%$ with most seaward station $\mathrm{S} 5$, discriminating species being Nereididae sp.2 and Neanthes sp. The lowest dissimilarities were found between two inner stations (61.72\%) and between two lower stations (64.76\%), the discriminating species were Nereididae sp. 3 and $\mathrm{Onu}$ phis conchylega. The dissimilarities between $\mathrm{S} 1$ and $\mathrm{S} 3$ was $84.89 \%$ and between S3 and S4 was $80.92 \%$, and the discriminating species were Corophiidae sp. and Onuphis conchylega. 


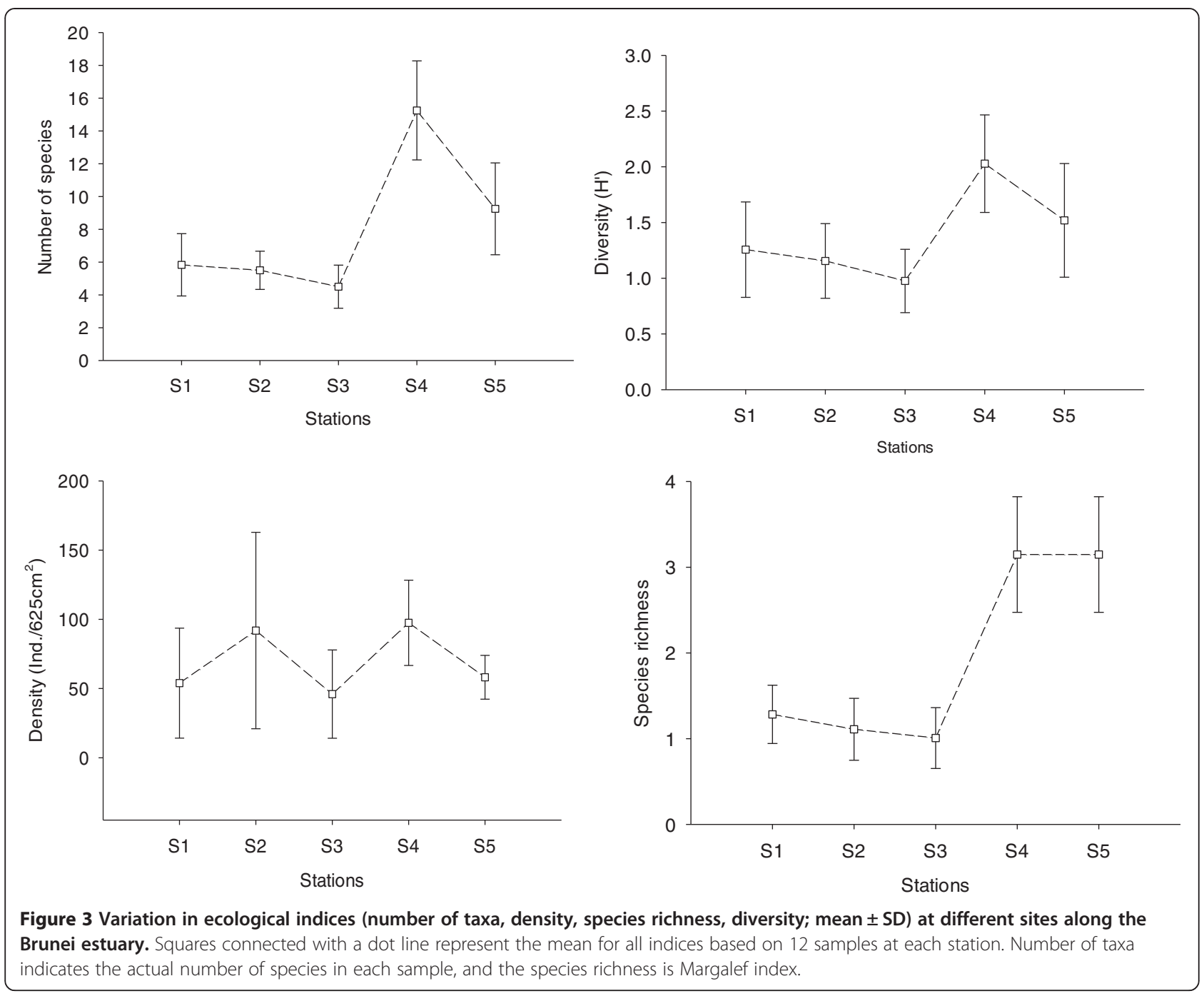

\section{Correlation between community parameters and environmental variables}

The Spearman's rank correlation analysis between the community parameters and the environmental variables indicated that all of the diversity indices were positively correlated with pore-water salinity and $\mathrm{pH}(\mathrm{p}<0.05)$ and negatively correlated with clay and organic matter, with the exception of evenness values $(p>0.05)$, which did not show any significant correlation with any of the environmental variables (Table 3). There was no significant correlation between community parameters and sand/ silt ( $\mathrm{p}>0.05)$.

\section{Relationship between the infaunal assemblage and environmental factors}

CCA for abundance of the 15 dominant species and six environmental variables produced an ordination plot in which the first two axes explain $71.31 \%$ of the variance in the species-environment relationships (Figure 5). The first axis showed highest positive correlation with salinity $(\mathrm{r}=0.83), \mathrm{pH}(\mathrm{r}=0.82)$ and percentage of sand $(\mathrm{r}=0.78)$, and a negative correlation with percentage of clay $(r=-0.84)$ and organic matter $(r=-0.74)$. This axis mainly reflected salinity and \% clay, which was closely related to the location of the stations. The second axis had the strongest negative correlation for a percentage silt $(r=-91)$. The CCA also revealed the relationships among 15 benthic infaunal species and environmental variables. Onuphis conchylega, Nereididae sp. 3, Goniada sp. Harpacticoida sp. Pilargidae sp., and Corophiidae sp. were placed on the right side of the plot. This indicates that the distribution of these taxa at the outer stations (i.e., high salinity/pH and sandy habitat) of the estuary. Neanthes sp., Nereididae sp.2, Cyclopoida sp. Prionospio sp, Potamilla leptochaeta, Spionidae sp. were found on the left side of the plot (lower salinity/pH and muddy habitat) suggesting these species are mainly distributed across the inner stations. Other dominant species 


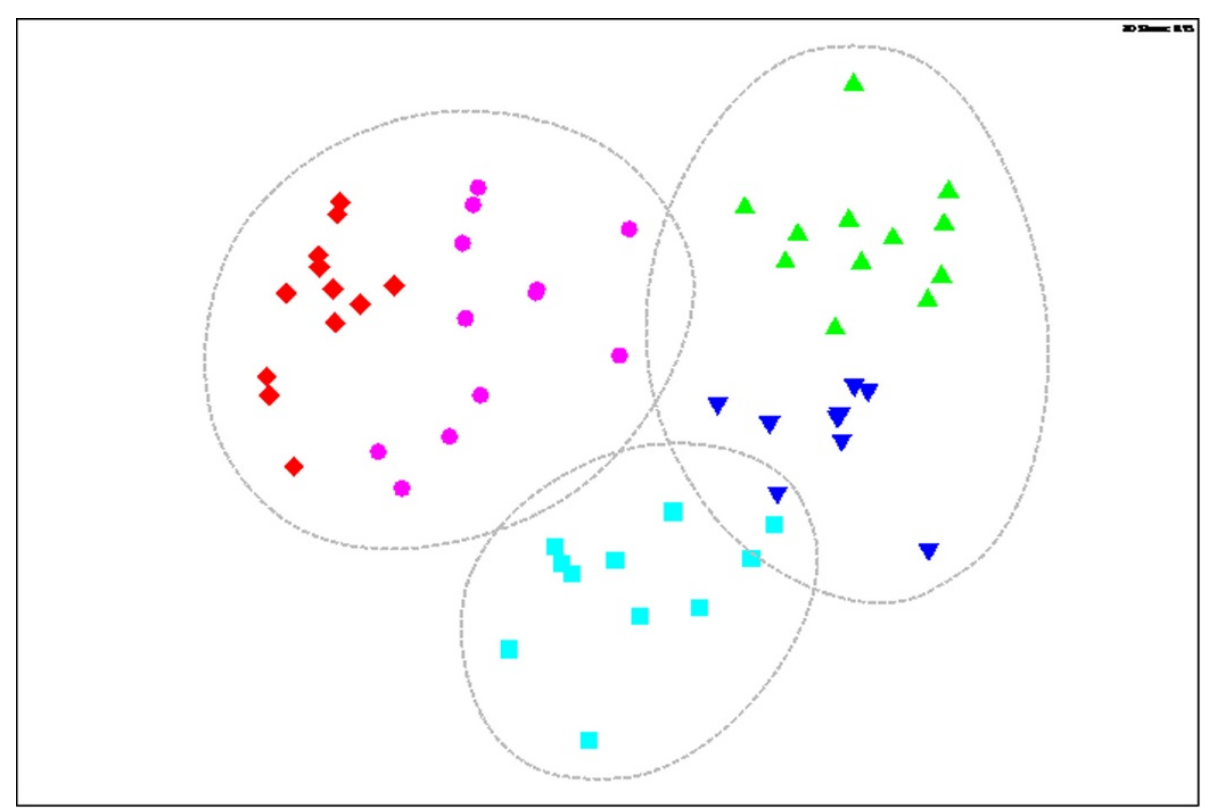

Figure 4 MDS ordination constructed from Bray-Curtis similarities showing spatial variations in infuanal assemblages in the Brunei Estuary. Data were presence/absence transformed. Key for the sites: Upward triangle: S1, Downward Triangle: S2, Square: S3, Circle: S4, Diamond = S5.

Capitellidae sp.1, Amphipoda sp. 2 and Sternaspis scutata, which were widely distributed along the estuary, fell near the origin of the plot.

\section{Discussion}

Analysis of the sediment pore-water showed a decline of salinity and $\mathrm{pH}$ from sea to landwards, like the pattern reported for overlying estuarine water salinity and $\mathrm{pH}$ [11]. The salinity gradient in overlying water, due to the interaction of incoming sea water and outflowing of freshwater, along the estuary from inner to lower reaches is an established fact [22,23]. Ram and Zingde [27] reported that the interstitial water chlorinity is sensitive to the changes in the composition of the overlying water up to a certain depth decided by factors such as sediment type, porosity, the diffusion rate and bioturbation. However, $\mathrm{pH}$ variation in estuarine systems is strongly influenced by biological activity in addition to physical factors. The lowering of above sediment estuarine water $\mathrm{pH}$ at the landward stations of the Brunei estuary is influenced by the massive acidic freshwater outflow, but also biogenically through the production of carbonic acid from bacterial decomposition of organic matter [11]. High $\mathrm{pH}$ at the seaward stations results from the buffering effect of sea water [28]. Sasekumar [29] reported the acidic $\mathrm{pH}$ value of pore-water (varied from 6.3-7.1) from a Malayan mangrove shore and suggested that the acidity was caused by the activity of bacteria on oxidizable sulphur. The $\mathrm{CO}_{2}$ arising from the decomposition of organic matter and animal respiration may also lower the $\mathrm{pH}$ values in the sediment pore-water [30,31].
Zhai et al. [31] reported a significant outgassing of $\mathrm{CO}_{2}$ from Pearl River estuary which was associated with decomposition of organic pollutants by aerobic respiration. The higher pore-water salinity compared to overlying water observed in this study (Figure 1) may be attributed to evaporation of sediment surface water as the intertidal sediment at low tide was exposed to air and sunlight during sampling. However, the pore-water $\mathrm{pH}$ in the estuary was less variable than overlying water at the same station.

The infaunal species composition was found to vary along the BES salinity/pH gradient, though most species were euryhaline. The taxa, Neanthes sp., Nereididae sp., Capitellidae sp., Potamilla leptochaeta, S. scutata, Cyclopoida sp., Leptochelia sp., extended along the length of the estuary, even tolerating salinities of $8 \mathrm{ppt}$, but showed greatest densities in the upper estuary. The stenohaline marine component was represented by the species Onuphis conchylega, Pholoe sp., Syllis sp, Pectinaria sp. and Calanoida sp., dominated in the lower estuary. Similar patterns of species distribution are known to occur in estuaries around the world [21,22,24,28]. However, the true estuarine organisms (living below $30 \mathrm{ppt}$ but not in the sea) are generally the most difficult to define [32]. Onuphis conchylega was most abundant in the middle reaches with abundance declining seaward and entirely absent at the upper low salinity stations, suggesting that it is a stenohaline species in this estuary.

Although there was no clear linear trend in community variables along the salinity/pH gradient as in the other estuaries $[22,33]$, species richness, density, diversity and number 


\begin{tabular}{lll}
$\begin{array}{l}\text { Table } 1 \text { Results of ANOSIM and pairwise tests for } \\
\text { differences on infaunal structure between stations and } \\
\text { sampling periods }\end{array}$ & R & p (\%) \\
\hline Global test & 0.977 & 0.1 \\
\hline Between stations & & \\
Stations compared & 0.852 & 0.1 \\
S1, S2 & 1 & 0.1 \\
S1, S3 & 1 & 0.1 \\
S1, S4 & 1 & 0.1 \\
S1, S5 & 0.972 & 0.1 \\
S2, S3 & 1 & 0.1 \\
S2, S4 & 0.954 & 0.1 \\
S2, S5 & 1 & 0.1 \\
S3, S4 & 0.954 & 0.1 \\
S3, S5 & 0.991 & 0.1 \\
S4, S5
\end{tabular}

The pairwise $\mathrm{R}$ values give absolute measure of how separated the groups are. $\mathrm{R}>0.75$ : groups being well separated; $\mathrm{R}>0.5$ : groups overlapping but clearly different; $R>0.25$ : groups barely separable at all. Bold types indicate separable communities.

Analyses performed on square-root transformed data.

of taxa in the benthic infauna were all positively related to salinity ( $p<0.05$ for all). This is due to a reduction in stenohaline species at the inner stations $[23,34]$ and lessened substrate diversity following a progression from sand at the lower reaches to mud at the upper reaches. The relationship between environmental variables and measured diversity indices explained this pattern as significant positive correlations were found for pore-water salinity, $\mathrm{pH}$ and \% sand, while a negative correlation was found between $\%$ clay and organic matter ( $\mathrm{p}<0.05)$ (Table 3$)$. For infaunal macroinvertebrates, sediment grain size has frequently been reported as a crucial factor in determining the structure of many benthic communities [22,35-40].

Most studies suggest that calcifying animals should be more affected by low $\mathrm{pH}$ waters than non-calcifiers $[3-5,15,41,42]$. However, our abundance data showed no different trend in distribution of calcifiers and noncalcifiers along the $\mathrm{pH}$ gradient. The high abundance of few calcifiers in inner low $\mathrm{pH}$ stations (Cyclopoida sp. in station S2 and the amphipod Corophiidae sp. in S3) essentially differs from the predicted trend $[15,43]$. The wide-ranging abundance of infaunal calcifiers may relate to (1) the reduced gradient in the pore-water in the BES, (2) adaptations to endure lowered pHs, (3) biological interactions where the predators are less tolerant of slightly higher acidic conditions. The high number of tolerant species in the acidic areas may also be due to the absence of metal sensitive predators [16]. Furthermore, organisms in coastal and estuarine waters have been experiencing low $\mathrm{pH}$ for several hundreds of years and consequently have potentially had time to adapt to low $\mathrm{pH}[3,42]$. Several groups of invertebrates are physiologically resistant to low $\mathrm{pH}$; for example, crabs can tolerate low $\mathrm{pH}$ through their physiological acid-base regulation $[3,19,44]$. Recent studies suggest that calcifiers are as sensitive to acidification as heavily calcified animals [3,15,41,42]. The findings of infaunal microcrustaceans (amphipods, isopods, cumaceans, tanaids, and copepods) are consistent with these previous findings suggesting a size-related difference in acidic vulnerability [5,15,42].

Many estuarine benthic studies [e.g., 22,33,45,46] have shown that community variables are principally correlated with water salinity, DO and sediment grain size, and this has been confirmed in the present study. Relatively few studies have explored the effect of $\mathrm{pH}$ on estuarine infaunal communities $[16,17]$. However, earlier work $[16,17]$ emphasized the relationships between water column parameters and benthic infauna, rather than focusing on the sediment pore-water, with which these organisms directly interact. Therefore, this the first study investigating the effect of pore-water $\mathrm{pH}$ on infaunal community structuring in a tropical estuary. Consequently, the unavailability of data constrains comparison. Nonetheless, the community level responses observed here are consistent with observations on the effects of acidification for other aquatic (marine) systems, including (1) a decrease in total community diversity [43], (2) a high abundance of crustaceans [15], and (3) a shift in the community composition [47].

In conclusion, this study shows that sediment particle size probably overrides effects of the above sediment water, and that the sediment (pore) water $\mathrm{pH}$ did not vary as much as the above water $\mathrm{pH}$ (primarily due to biogenic acidification of the pore-water). The implication of the latter is that coastal infaunal communities may be less affected by water $\mathrm{pH}$ variations caused by various ways including elevation in atmospheric $\mathrm{CO}_{2}$ than what has been described for epibenthic communities.

\section{Materials and methods Study site}

The BES (Figure 6) constitutes the Inner Brunei Bay and three major river systems (Sungai Limbang, Sungai Temburong and Sungai Brunei) flanked by the South China Sea, Brunei and Malaysia in North-western Borneo $\left(1^{\circ} 00^{\prime}\right.$ $00^{\prime \prime} \mathrm{N}$ and $\left.114^{\circ} 00^{\prime} 00^{\prime \prime} \mathrm{E}\right)$. It occupies an area of $1380 \mathrm{~km}^{2}$. The equatorial tropical climate in the region ensures high rainfall and temperature conditions throughout the year, with regular freshwater inflow into the shallow $(<5 \mathrm{~m}$ depth) and well-mixed system [26]. The shoreline is fringed predominantly (75\%) by Rhizophora mangrove forests [48]. The tides are mainly diurnal with semi-diurnal on a few days, and the daily tidal amplitude ranges from about to $0.9 \mathrm{~m}$ to $2.0 \mathrm{~m}$ at the estuarine mouth. Although the agricultural and industrial sectors in the region are under-developed, the estuary is subject to significant 
Table 2 SIMPER similarity analysis of infaunal species within stations along salinity-pH gradient

\begin{tabular}{|c|c|c|c|c|c|}
\hline Species & Average abundance & Average similitude & Similitude/SD & Contribution \% & Cumulative \% \\
\hline \multicolumn{6}{|l|}{ Station S1 } \\
\hline \multicolumn{6}{|l|}{ Average similarity: 52.65} \\
\hline Nereididae sp.2 & 4.28 & 23.09 & 2.52 & 43.86 & 43.86 \\
\hline Prionospio sp & 2.35 & 11.02 & 3.01 & 20.94 & 64.80 \\
\hline Cyclopoida sp. & 1.68 & 5.73 & 0.77 & 10.89 & 75.69 \\
\hline Neanthes sp. & 1.79 & 5.10 & 0.98 & 9.69 & 85.38 \\
\hline Potamilla leptochaeta & 1.84 & 3.37 & 0.60 & 6.40 & 91.77 \\
\hline \multicolumn{6}{|l|}{ Station S2 } \\
\hline \multicolumn{6}{|c|}{ Average similarity: 54.96} \\
\hline Neanthes sp. & 5.74 & 19.25 & 1.48 & 35.03 & 35.03 \\
\hline Cyclopoida sp. & 3.83 & 14.39 & 3.23 & 26.19 & 61.21 \\
\hline Nereididae sp.2 & 2.91 & 9.27 & 1.25 & 16.87 & 78.08 \\
\hline Capitellidae sp.1 & 1.93 & 7.65 & 1.81 & 13.91 & 91.99 \\
\hline \multicolumn{6}{|l|}{ Station S3 } \\
\hline \multicolumn{6}{|l|}{ Average similarity: 59.87} \\
\hline Corophiidae sp. & 4.71 & 27.80 & 2.82 & 46.44 & 46.44 \\
\hline Capitellidae sp.1 & 2.17 & 16.54 & 2.57 & 27.63 & 74.07 \\
\hline Neanthes sp. & 2.69 & 11.42 & 1.08 & 19.07 & 93.14 \\
\hline \multicolumn{6}{|l|}{ Station 54} \\
\hline \multicolumn{6}{|l|}{ Average similarity: 62.53} \\
\hline Onuphis conchylega & 4.91 & 11.52 & 1.88 & 18.42 & 18.42 \\
\hline Nereididae sp. 3 & 3.97 & 9.76 & 2.92 & 15.61 & 34.03 \\
\hline Capitellidae sp.1 & 3.01 & 7.97 & 5.03 & 12.75 & 46.79 \\
\hline Goniada sp. & 3.14 & 5.73 & 1.15 & 9.17 & 55.95 \\
\hline Magelona sp. & 1.66 & 4.19 & 4.39 & 6.70 & 62.66 \\
\hline Pilargidae sp. & 1.70 & 3.96 & 1.87 & 6.34 & 69.00 \\
\hline Maldanidae sp. & 1.38 & 3.18 & 1.72 & 5.09 & 74.09 \\
\hline Pholoe sp. & 1.37 & 2.48 & 1.04 & 3.97 & 78.06 \\
\hline Nephtys sp. & 1.11 & 2.17 & 1.01 & 3.47 & 81.53 \\
\hline Corophiidae sp. & 1.01 & 1.70 & 0.82 & 2.71 & 84.24 \\
\hline Spionidae sp. & 0.89 & 1.48 & 0.83 & 2.36 & 86.60 \\
\hline Harpacticoida sp. & 1.06 & 1.40 & 0.65 & 2.24 & 88.84 \\
\hline Paranthuridae sp. & 1.00 & 1.31 & 0.65 & 2.10 & 90.94 \\
\hline \multicolumn{6}{|l|}{ Station S5 } \\
\hline \multicolumn{6}{|c|}{ Average similarity: 46.79} \\
\hline Capitellidae sp.1 & 2.55 & 9.88 & 3.54 & 21.11 & 21.11 \\
\hline Goniada sp. & 2.20 & 7.91 & 1.65 & 16.91 & 38.02 \\
\hline Neanthes sp. & 3.05 & 7.14 & 0.71 & 15.26 & 53.27 \\
\hline Pilargidae sp. & 1.67 & 5.66 & 1.70 & 12.10 & 65.38 \\
\hline Onuphis conchylega & 1.82 & 4.76 & 0.88 & 10.16 & 75.54 \\
\hline Harpacticoida sp. & 1.28 & 3.21 & 1.01 & 6.86 & 82.40 \\
\hline Prionospio sp & 0.94 & 3.04 & 1.06 & 6.51 & 88.91 \\
\hline Amphipoda sp. 2 & 1.66 & 2.11 & 0.45 & 4.51 & 93.41 \\
\hline
\end{tabular}


Table 3 Spearman's rank correlation coefficients $(r)$ between environmental and community variables estimated for all species

\begin{tabular}{llllll}
\hline Variables & Number of species $(\mathbf{S})$ & Density $(\mathbf{D})$ & Richness (d) & Diversity (H') & Evenness $\left(\mathbf{J}^{\prime}\right)$ \\
\hline Salinity & $0.648^{* * *}$ & $0.279^{*}$ & $0.573^{* * * *}$ & $0.446^{* * *}$ & $0.010 \mathrm{~ns}$ \\
$\mathrm{pH}$ & $0.637^{* * *}$ & $0.315^{*}$ & $0.562^{* * * *}$ & $0.492^{* * *}$ & $0.118 \mathrm{~ns}$ \\
Sand & $0.114 \mathrm{~ns}$ & $0.018 \mathrm{~ns}$ & $0.150 \mathrm{~ns}$ & $0.0565 \mathrm{~ns}$ & $0.007 \mathrm{~ns}$ \\
Silt & $-0.114 \mathrm{~ns}$ & $-0.018 \mathrm{~ns}$ & $-0.150 \mathrm{~ns}$ & $-0.0565 \mathrm{~ns}$ & $-0.007 \mathrm{~ns}$ \\
Clay & $-0.451^{* * *}$ & $-0.107 \mathrm{~ns}$ & $-0.450^{* * *}$ & $-0.349^{* *}$ & $-0.096 \mathrm{~ns}$ \\
OM & $-0.570^{* * * *}$ & $-0.030 \mathrm{~ns}$ & $-0.581^{* * *}$ & $-0.390^{* *}$ & $-0.056 \mathrm{~ns}$ \\
\hline
\end{tabular}

${ }^{*} p<0.05, * * p<0.01,{ }^{* * *} p<0.001,{ }^{* * *} p<0.0001$.

solid waste pollution, including treated and untreated sewage and domestic waste from traditional water villages, urban developments (Bandar Seri Begawan, Kuilap and Gadong $[11,49]$.

The estuary is naturally acidic, primarily due to eutrophication, heterotrophic metabolism and associated acid sulphate groundwater seeps [11]. Consequently, a steep cline in estuarine water salinity and $\mathrm{pH}$ extends across the system; low salinity/pH landwards and high salinity/pH seawards. Five study stations were established along the northern edge of the Inner Brunei Bay and Sungai Brunei estuary (Figure 6).

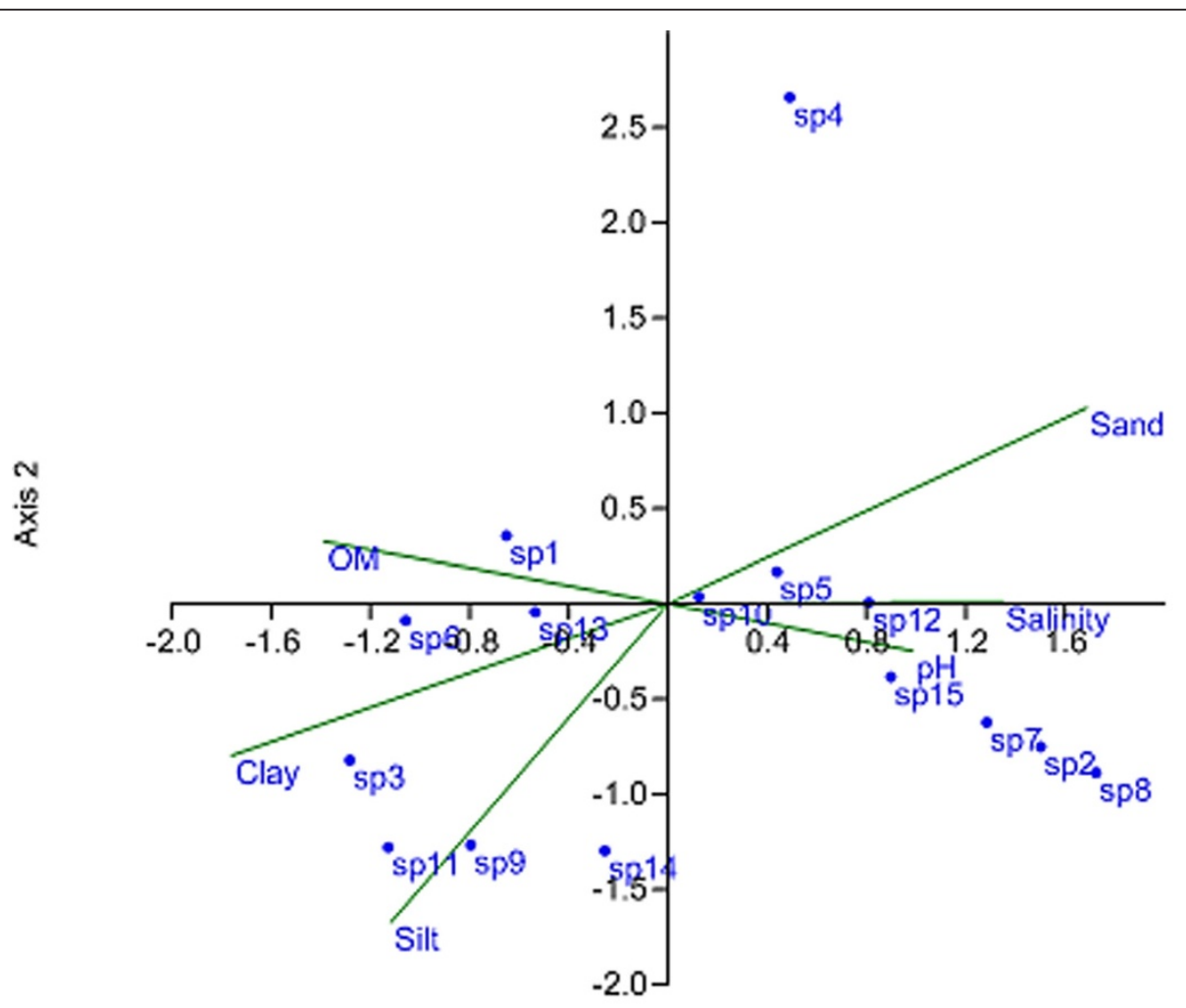

Axis 1

Figure 5 Canonical correspondence analysis (CCA) ordination diagrams for infaunal species abundance data (occurred $>1 \%$ of total abundance). Species scores along the first and second axes in relation to environmental variables. Sediment parameters reported in Hossain et al. [26] were used. Environmental data were square root/ log transformed as necessary. The environmental variables are shown as line vectors, and the directions of which are obtained from the correlation of the variable to the axes. Species: $\mathrm{sp} 1=$ Neanthes sp; sp2 = Onuphis conchylega; $\mathrm{sp} 3=$ Nereididae sp.2; sp4 = Amphipoda sp.1; sp5 = Capitellidae sp.1; sp6 = Cyclopoida sp.; sp7 = Goniada sp.; sp8 = Nereididae sp. 3; sp9 = Prionospio sp.; sp10 = Amphipoda sp.1; sp11 = Potamilla leptochaeta, sp12 = Pilargidae sp.; sp13 = Sternaspis scutata; sp14 = Spionidae sp.; sp15 = Harpacticoida sp. 




\section{Pore-water salinity and $\mathrm{pH}$ determination}

At each station, in situ $\mathrm{pH}$ and salinity of low-tide sediment pore-water was determined. A pit of $20 \mathrm{~cm}$ in depth was dug using spade, and $\mathrm{pH}$ and salinity of the water seep was measured using Hach HQ series portable salinity meters (CDC 401-01, USA) and Mettler Toledo $\mathrm{pH}$ probe (Type 1120, Germany) calibrated with Mettler Toledo SRM NIST precision buffer solution (using $\mathrm{pH} 4$, 7, and 10 standards). In each field visit at least five stabilized readings were taken from each sampling spot. Details of methodology and results for sediment properties (\% of sand, silt, clay and organic matter) were reported in the earlier study [26].

\section{Infaunal sampling and determination}

Macrobenthic infauna were sampled at five stations in Brunei estuary (Figure 6) on four occasions from July 2011 to June 2012. Stations 1 and 2, in the upper reaches of the estuary, had a muddy black bottom which was anoxic and with the smell of $\mathrm{H}_{2} \mathrm{~S}$. Station 3, located in the upper reaches but with sandy mud bottom and station 4 and 5, at the lower end of the estuary, had a sandy mud bottom. Three replicate samples were taken at each station from mid-intertidal area on each date. One additional core was taken from each station for determination of sediment physical characteristics. Sediment samples were excavated from an area of $25 \mathrm{~cm} \times 25 \mathrm{~cm}$ with a depth of 
$20 \mathrm{~cm}$ by using a spade during low tide. Excavated sediment samples were put into polyethylene bag and carried to the laboratory where sediment samples were washed through $0.5 \mathrm{~mm}$ mesh sieve with tap water. Detritus and organisms retained by the sieve were stained in dilute Rose Bengal and fixed in 5\% formalin for one day. The formalin was later washed out and specimens were preserved in $70 \%$ ethanol. Individuals were separated from the sediment and detritus under a dissecting microscope and preserved and kept in small vials of ethanol for future identification. Animals were identified to the lowest known taxonomic level using available identification sources [e.g., 48-54]. Within each family, fauna were distinguished as 'morphospecies' [55]. The taxonomic status was checked and updated using the web portal WORMS (www.marinespecies.org). Densities of taxa (number of individuals/ $625 \mathrm{~cm}^{2}$ surface area) were determined by counting all organisms in samples. Only the dominant taxa (Polychaeta and Crustacea) were used in the analysis and we assumed interacted closely with the sediment pore-water. All the specimens are deposited in the Biology Department museum, Universiti Brunei Darussalam, Brunei.

\section{Statistical analysis}

Univariate statistical analyses were undertaken to determine for each station the number of species (taxa), average density (D), Margalef's species richness (d), Pielou's evenness $\left(J^{\prime}\right)$, Shannon-Weiner diversity ( $\mathrm{H}^{\prime}$, loge base). On the assumption that the data were not normally distributed, nonparametric Kruskal-Wallis ANOVA and Mann-Whitney pair-wise comparison tests were performed to assess significant differences in the diversity indices among sites. These analyses were run using PAST [56]. Multivariate statistics were used to investigate variations in the structure of the infaunal community throughout the study period. A BrayCurtis similarity matrix was computed using abundances of fauna, from which cluster analysis and the non-metric multidimensional scaling (MDS) ordination plot was generated (based on presence/absence transformed data) to visualize the patterns in the spatial distribution using PRIMER V.6 [57,58]. The programme was also used to compute a two-way analysis of similarity (ANOSIM), to determine significant spatial variation in the faunal communities. Taxa making the highest contribution to the differences were detected using SIMPER (PRIMER).

Spearman's rank correlations were calculated to show the relationship between univariate measures and environmental parameters. Sediment parameters reported in Hossain et al. [26] were used in order to provide a basis for interpretation of the biological variables. Associations between assemblage patterns and environmental variables were quantified via canonical correspondence analysis (CCA), a nonlinear eigenvector ordination technique related to CA but which constrains the axes to be linear combinations of the measured environmental variables (run in PAST).

\section{Competing interests}

The authors declare that they have no competing interests.

\section{Authors' contributions}

This is Postgraduate research (Ph.D.) work of the first author. DJM supervised the work and contributed to this study significantly, and were involved at different times: sampling designing, data analyzing and improving the English language. Both authors read and approved the final manuscript.

\section{Acknowledgments}

$\mathrm{MBH}$ is indebted to UBD for providing GRS scholarship. We gratefully acknowledge the financial support provided through the UBD grant number UBD/GSR/S\&T/16. The authors are grateful to Editor-in- Chief and anonymous referee for their constructive comments and suggestions which led to significant improvements to the manuscript.

Received: 4 August 2014 Accepted: 22 October 2014

Published: 6 November 2014

\section{References}

1. Dove CM, Sammut J: Impacts of estuarine acidification on survival and growth of sydney rock oysters Saccostrea glomerata (Gould 1850). J Shellfish Res 2007, 26:519-527.

2. Salisbury J, Green M, Hunt C, Campbell J: Coastal acidification by rivers: a threat to shellfish? EOs 2008, 89:513-528.

3. Amaral V, Cabral HN, Bishop MJ: Resistance among wild invertebrate populations to recurrent estuarine acidification. Estuar Coast Shelf Sci 2011, 93:460-467.

4. Amaral V, Cabral HN, Bishop MJ: Effects of estuarine acidification on predator-prey interactions. Mar Ecol Prog Ser 2012, 445:117-127.

5. Amaral V, Cabral HN, Bishop MJ: Prior exposure influences the behavioural avoidance by an intertidal gastropod, Bembicium auratum, of acidified waters. Estuar Coast Shelf Sci 2014, 136:82-90.

6. U.S. Environmental Protection Agency (USEPA): pH and Alkalinity. In Voluntary Estuary Monitoring Manual. Washington DC: USEPA Office of Water; 2006:1-13. Available at http://water.epa.gov/type/oceb/nep/upload/ 2009_03_13_estuaries_monitor_chap11.pdf.

7. Sammut J, Melville MD, Callinan RB, Fraser GC: Estuarine acidification: impacts on aquatic biota of draining acid sulfate soils. Aust Geogr Stud 1995, 33:89-100.

8. Knutzen J: Effects of decreased pH on marine organisms. Mar Pollut Bull $1981,12: 25-29$.

9. Amaral V, Cabral HN, Bishop MJ: Moderate acidification affects growth but not survival of 6-month-old oysters. Aquat Ecol 2012, 46:119-127.

10. Guinotte JM, Fabry VJ: Ocean acidification and its potential effects on marine ecosystems. Ann N Y Acad Sci 2008, 1134:320-342.

11. Marshall DJ, Santos JH, Leung KMY, Chak WH: Correlations between gastropod shell dissolution and water chemical properties in a tropical estuary. Mar Environ Res 2008, 66:422-429.

12. Caldeira K, Wickett ME: Oceanography: anthropogenic carbon and ocean pH. Nature 2003, 425:365.

13. Orr JC, Fabry VJ, Aumont O, Bopp L, Doney SC, Feely RA, Gnanadesikan A, Gruber N, Ishida A, Joos F, Key RM, Lindsay K, Maier-Reimer E, Matear R, Monfray P, Mouchet A, Najjar RG, Plattner GK, Rodgers KB, Sabine CL, Sarmiento JL, Schlitzer R, Slater RD, Totterdell IJ, Weirig MF, Yamanaka Y, Yool A: Anthropogenic ocean acidification over the twenty-first century and its impact on calcifying organisms. Nature 2005, 437(7059):681-686.

14. Feely RA, Simone RA, Newton J, Sabine CL, Warner M, Devol C, Krembs MC: The combined effects of ocean acidification, mixing, and respiration on $\mathrm{pH}$ and carbonate saturation in an urbanized estuary. Estuar Coast Shelf Sci 2010, 88:442-449.

15. Kroeker KJ, Micheli F, Gambi MC, Martz TR: Divergent ecosystem responses within a benthic marine community to Ocean acidification. Proc Natl Acad Sci U S A 2011, 108:14515-14520.

16. Roach AC: The effect of acid water inflow on the estuarine benthic and fish communities in the Richmond River, NSW Australia. Australas J Ecotoxicol 1997, 3:25-56. 
17. Corfield J: The effects of acid sulphate run-off on a subtidal estuarine macrobenthic community in the Richmond River, NSW, Australia. ICES J Mar Sci 2000, 57:1517-1523.

18. Lohbeck KT, Riebesell U, Reusch TB: Adaptive evolution of a key phytoplankton species to ocean acidification. Nat Geosci 2012, 5(5):346-351.

19. Wittmann AC, Pörtner HO: Sensitivities of extant animal taxa to ocean acidification. Nat Clim Chang 2013, 3:995-1001.

20. Teske PR, Wooldridge TH: What limits the distribution of subtidal macrobenthos in permanently open and temporarily open/closed South African estuaries? Salinity vs. sediment particle size. Estuar Coast Shelf Sci 2003, 57:225-238.

21. Warwick RM: Comparative study of the structure of some tropical and temperate marine soft-bottom macrobenthic communities. Mar Biol 1987, 95(4):641-649.

22. Ysebaert T, Herman PMJ, Meire P, Craeymeersch J, Verbeek H, Heip CHR: Large-scale spatial patterns in estuaries: estuarine macrobenthic communities in the Schelde estuary, NW Europe. Estuar Coast Shelf SCi 2003, 57:335-355.

23. McLusky DS, Elliot M: The Estuarine Ecosystem: Ecology, Threats, and Management. 3rd edition. Oxford: Oxford University Press; 2006.

24. Barnes RSK: Distribution patterns of macrobenthic biodiversity in the intertidal seagrass beds of an estuarine system, and their conservation significance. Biodivers Conserv 2013, 22:357-372.

25. McLusky DS, Hull SC, Elliott M: Variations in the intertidal and subtidal macrofauna and sediments along a salinity gradient in the Upper Forth estuary. Neth J Aquat Ecol 1993, 27:101-109.

26. Hossain MB, Marshall DJ, Senapathi V: Sediment granulometry and organic matter content in the intertidal zone of the Sungai Brunei estuarine system, northwest coast of Borneo. Carpathian J Earth Environ Sci 2014 9(2):231-239.

27. Ram A, Zingde MD: Interstitial water chemistry and nutrients fluxes from tropical intertidal sediment. Indian J Mar Sci 2000, 29(4):310-318.

28. Day JW, Hall CAS, Kemp WM, Yanez-Arancibia A: Estuarine Ecology. New York: J. Wiley and Sons; 1989:558.

29. Sasekumar A: Distribution of macrofauna on a Malayan mangrove shore. $J$ Anim Ecol 1974, 43(1):51-69.

30. Zhai W, Dai $\mathrm{M}, \mathrm{Guo} X$ : Carbonate system and $\mathrm{CO}_{2}$ degassing fluxes in the inner estuary of Changjiang (Yangtze) River. Chin Mar Chem 2007, 107(3):342-356

31. Zhai W, Dai $M$, Cai WJ, Wang $Y$, Wang Z: High partial pressure of $\mathrm{CO}_{2}$ and its maintaining mechanism in a subtropical estuary: the Pearl River estuary. Chin Mar Chem 2005, 93(1):21-32.

32. Gray JS, Elliott M: Ecology of Marine Sediments: science to management. 2nd edition. Oxford: Oxford University Press; 2009:225

33. Selleslagh J, Lobry J, N'Zigou AR, Bachelet G, Blanchet $H$, Chaalali, Sautour $A B$, Boet $P$ : Seasonal succession of estuarine fish, shrimps, macrozoobenthos and plankton: physico-chemical and trophic influence. The Gironde Estuary as a Case Study. Estuar Coast Shelf Sci 2012, 112:243-254.

34. Telesh I, Schubert H, Skarlato S: Life in the salinity gradient: Discovering mechanisms behind a new biodiversity pattern. Estuar Coast Shelf Sci 2013, in Press.

35. Gray JS: Animal-sediment relationships. Oceanogr Mar Biol Ann Rev 1974, 12(223):61

36. Anderson MJ, Ford RB, Honeywill C, Feary D: Quantitative measures of sedimentation in an estuarine system and its relationship with intertidal soft-sediment infauna. Mar Ecol Prog Ser 2004, 272:33-48.

37. Giménez L, Dimitriadis C, Carranza A, Borthagaray Al, Rodríguez M: Unravelling the complex structure of a benthic community: a multiscalemultianalytical approach to an estuarine sandflat. Estuar Coast Shelf Sci 2006, 68:462-472.

38. Norkko A, Thrush SF, Hewitt JE, Cummings VJ, Norkko J, Ellis Jl, MacDonald I: Smothering of estuarine sandflats by terrigenous clay: the role of windwave disturbance and bioturbation in site-dependent macrofaunal recovery. Mar Ecol Prog Ser 2002, 234:23-42.

39. Ysebaert T, Herman PM: Spatial and temporal variation in benthic macrofauna and relationships with environmental variables in an estuarine, intertidal soft-sediment environment. Mar Ecol Prog Ser 2002, 244:105-124.
40. Giménez L, Venturini N, Kandratavicius N, Hutton M, Lanfranconi A, Rodríguez M, Muniz P: Macrofaunal patterns and animal-sediment relationships in Uruguayan estuaries and coastal lagoons (Atlantic coast of South America). J Sea Res 2014, 87:46-55.

41. Hendriks IE, Duarte CM, Alvarez M: Vulnerability of marine biodiversity to ocean acidification: a meta-analysis. Estuar Coast Shelf Sci 2010, 86:157-164

42. Hofmann GE, Barry JP, Edmunds PJ, Gates RD, Hutchins DA, Klinger T, Sewell $M A$ : The effect of ocean acidification on calcifying organisms in marine ecosystems: an organism-to-ecosystem perspective. Annu Rev Ecol Evol Syst 2010, 41:127-147.

43. Hall-Spencer JM, Rodolfo-Metalpa R, Martin S, Ransome E, Fine M, Turner SM, Buia MC: Volcanic carbon dioxide vents show ecosystem effects of ocean acidification. Nature 2008, 454(7200):96-99.

44. Pörtner $\mathrm{HO}$ : Ecosystem effects of ocean acidification in times of ocean warming: a physiologist's view. Mar Ecol Prog Ser 2008, 373:203-217.

45. Hampel $H$, Elliott M, Cattrijsse A: Macrofaunal communities in the habitats of intertidal marshes along the salinity gradient of the Schelde estuary. Estuar Coast Shelf Sci 2009, 84:45-53.

46. Hossain MB: Macrobenthic Community Structure from a Tropical Estuary. Germany: LAP publishing company; 2011:84

47. Traister EM, McDowell WD, Krám P, Fottová D, Kolaříková K: Persistent effects of acidification on stream ecosystem structure and function. Freshw Sci 2013, 32:586-596.

48. Chua T-E, Chou LM, Sadorra MSM: The coastal environmental profile of Brunei Darussalam: resource assessment and management issues. Brunei Darussalam: ICLARM Technical Report 18, Fisheries Department, Ministry of Development; 1987:193.

49. Fauvel P: The Fauna of India, including Pakistan, Ceylon, Burma and Malaya. Annelida Polychaeta. Allahabad: The Indian Press; 1953:507.

50. Day JH: A monograph of the Polychaeta of Southern Africa. Lond Br Nat Hist Mus 1967, 1:458

51. Fauchald K: The polychaete worms, definitions and keys to the orders, families and genera. Nat Hist Mus Los Angeles Cty: Los Angeles CA (USA) SCi Ser 1977, 28:1-188.

52. Day JH: A monograph of the polychaeta of Southern Africa. Lond Br Nat Hist Mus 1967, 2:420

53. Hutchings $P$, Reid $A$ : The Nereididae (Polychaeta) from Australia Leonnates, Platynereis and Solomononereis. Rec Aust Mus 1991, 43:47-62.

54. Barnes RD, Ruppert EE: Invertebrate Zoology. USA: Brooks; 1994:928.

55. Oliver I, Beattie AJ: A possible method for the rapid assessment of biodiversity. Conserv Biol 1993, 7:562-568.

56. Hammer $\varnothing$, Harper DAT, Ryan PD: PAST: paleontological statistics software package for education and data analysis. Palaeontol Electron 2004, 4, art. 4.

57. Clarke KR, Warwick RM: Change in Marine Communities: An Approach to Statistical Analysis and Interpretation. Plymouth: Plymouth Marine Laboratory; 2001:172.

58. Clarke KR, Gorley RN: PRIMER v.6: User Manual/Tutorial. Plymouth: PRIMER-E; 2006.

doi:10.1186/2046-9063-10-11

Cite this article as: Hossain and Marshall: Benthic infaunal community structuring in an acidified tropical estuarine system. Aquatic Biosystems 2014 10:11.

\section{Submit your next manuscript to BioMed Central and take full advantage of:}

- Convenient online submission

- Thorough peer review

- No space constraints or color figure charges

- Immediate publication on acceptance

- Inclusion in PubMed, CAS, Scopus and Google Scholar

- Research which is freely available for redistribution 